\title{
Being Involved with Your School-Age Child ${ }^{1}$
}

Millie Ferrer, Anne M. Fugate and Ingrid Rivera²

\section{Introduction}

When parents hear the term "parental involvement," they often think of being involved in their child's education. School involvement is important, but parental involvement goes much further. Parental involvement means being genuinely involved in every part of your child's life. In order to do this, you must make time for your child every day.

Many parents want to be actively involved in their child's life, but they may find it difficult to connect with their child. This publication talks about how to make meaningful connections with your child.

\section{The Importance of Spending Time Together}

Because today's families seem to be busier than ever, parents must make more of an effort to set aside time to spend with their child. The time you give your child is priceless. By spending time with your child, you are sending him the message that he is worthy of your love and attention. This is a very important message for your child to receive. It shapes his view of himself, his interests, and his goals.
As a parent, you may have heard about the importance of spending quality time with your child. A good definition of quality time is "time spent doing something that both parent and child find meaningful and enjoyable.” However, this phrase can be misleading. It suggests that parents do not have to spend a lot of time with their child. The only way to truly get to know your child is to spend a lot of time with her. Through your ongoing interaction, you will learn about her likes, dislikes, strengths, weaknesses, hopes, and dreams. Spending time together is crucial to developing a warm and supportive relationship with your child.

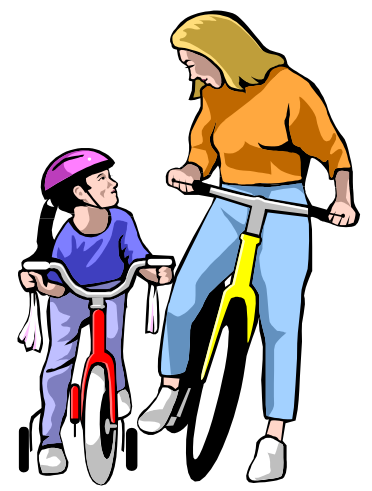

1. This document is FCS2204 one of a series of the Department of Family, Youth and Community Sciences, Florida Cooperative Extension Service, Institute of Food and Agricultural Sciences (IFAS), University of Florida. Publication date: December 2002, Updated July 2003. Reviewed by: Meredith Taylor, MS, CED, extension. agent. IV, Live Oak, FL and Betty Miller, Ph.D., extension. agent. IV, Tallahassee, FL. Please visit the EDIS Web site at http://edis.ifas.ufl.edu

2. Millie Ferrer, Ph.D., professor, Anne M. Fugate, former coordinator Educational/Training Programs, Ingrid Rivera, former graduate assistant, Department of Family, Youth and Community Sciences, Cooperative Extension Service, Institute of Food and Agricultural Sciences, University of Florida, Gainesville, 32611. 
The term quality time might also suggest that the time you spend together is in short bursts of planned activities. However, any time you spend together can be meaningful and enjoyable. Even doing something ordinary, such as going to the store together, can reinforce your relationship with your child.

When you are available to your child every day, she will feel that you are truly there for her when she needs you. Your child will feel more comfortable coming to you when she wants to talk about a problem or when she has exciting news to share. Also, when your child knows that you are there for her, your parenting will be more effective. When you develop a warm, supportive, and trusting relationship with your child, she will be more willing to accept necessary rules and expectations.

\section{Ways to Spend Time Together}

When your child was a preschooler, it was easier to spend time with him. He was less independent and had fewer relationships outside the family. Now that he is in elementary school, he is developing more friendships and interests of his own. He is probably involved in activities outside the home. Although your child is becoming more independent and enjoys spending time with his peers, there are still a number of ways you can spend time with him.

\section{Play Together}

One of the best ways to spend time with your child is to play with her. Playing together is a good way to get to know your child. It also teaches her many important social skills, such as taking turns, negotiating, following rules, fairness, and communication.

When playing with your child, be attentive to him and follow his lead. Avoid taking over the game. For example, if your child is playing with action figures and asks you to be a particular character, go along with his request. You can let your child know that you are focused on him by narrating what he is doing in his play. For example, when he is playing with his action figures you might say, "I see you're rescuing the townspeople from the bad guy." Narrating will often encourage children to explain or expand on what they are doing. Narrating will also help you to follow your child's lead instead of telling him what to do.

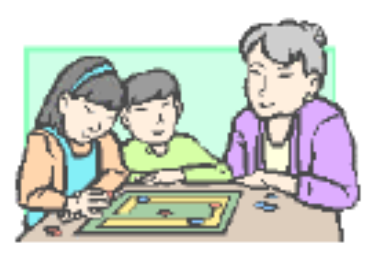

Also, when you play board games or sports with your child, emphasize playing just for the fun of it. If your child puts herself down or gets angry for making a mistake, remind her

that it is just a game and getting too serious about winning just spoils the fun of being together. Do not criticize or belittle yourself, either, when you make a mistake or lose. Children model what they see. Being a good sport and having a sense of humor will only make your relationship better.

Remember, when you play just for fun, you send your child the crucial message that what is important to you is spending time together.

\section{Eat Together}

Eating together is a perfect way to spend time with your child. It gives you a chance to talk with each other, away from TV and other distractions. To make mealtime talk enjoyable, start positive conversations. For example, ask your child "what was the best thing that happened to her today". Avoid discussing chores or behavior issues at mealtime. 


\section{Invite Your Child's Friends Over to Play}

Most school-age children spend their free time playing with friends. The time they spend with their friends is important to their social development. It might seem that having friends over to play is not spending time with your child, but think of it as spending time with him indirectly. Having your child's friends over lets you get to know them better. You will know your child's whereabouts and the activities he is involved in. It also lets your child know that you are his ally and that you are interested in him. You are sending the message that you are happy to have him around and home is a good place to bring friends.

\section{Support Your Child's Interests}

Your school-age child is developing her own interests. These interests help your child expand her outlook and develop skills she will carry into adulthood.

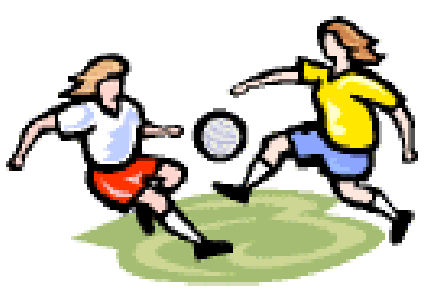

Supporting your child's interests is a good way to spend time with her. You can support her interests in many ways. For example, if your child plays soccer, you could cheer for her at her games or help her practice. If she is interested in insects, you could take her to a museum exhibit or ask her to take you on an insect safari in the backyard. If she is interested in Girl Scouts or 4$\mathrm{H}$, you could volunteer as a leader.

Just make sure that you really are supporting your child's interests. Do not push her to do something just because you like it. Also, understand that supporting your child's interests means being there, listening, and encouraging. Avoid judging or criticizing her interests or performance.

If your child has many interests, help her choose a few she will be successful at and will enjoy participating in. Do not fall into the trap of overcommitting your child with teams, clubs, and classes. Disregard the notion that the more activities your child is involved in, the better. Children need unstructured time to enjoy their childhood. They need time to relax and take pleasure in the simple things life has to offer.

\section{Make the Most of Waiting Time and Daily Routines}

Even during a busy day, you can spend time with your child by making the most of waiting time and routine activities. For example, if your child enjoys singing, sing songs in the car when you are running errands. This is also the perfect opportunity to start a conversation with your child. Instead of being frustrated by traffic, you can use this time to catch up on what is going on in your child's life. During a trip to the supermarket, you can play games such as "I Spy" or you can let your child help by finding the coupon items. If you are waiting at the car repair shop, read a book together or take turns adding to a silly drawing. You can take advantage of waiting time and routine activities by interacting with your child in fun and creative ways.

\section{Have Regular Family Activities}

A good way for a busy family to spend time together and stay connected is through regular family activities. In fact, the busier a family is, the more important it is to plan regular family time. Do not wait for a spare moment or leftover time to plan activities with your family.

A family activity can be a vacation or trip to an amusement park, but it does not have to be elaborate or expensive. Family activities can be going on a picnic, going to the park, playing 
board games, or baking cookies. They can be renting a video and making popcorn or going to a local ball game. It does not matter what you do, as long as the family has fun together regularly. As children get older and develop their own interests, it will be more difficult to plan activities that every family member enjoys. Try to combine family members' favorite activities. You can also alternate them. Be sure your child is included in the planning of family activities.

\section{Celebrate Family Traditions}

Celebrating family traditions helps build and strengthen the bond with your child. Family traditions can be elaborate, once-a-year events, such as a special holiday dinner or a spring camping trip. They can be simple, more frequent events, such as Sunday morning pancakes or evening walks. Whether elaborate or simple, a share tradition becomes a special family time.

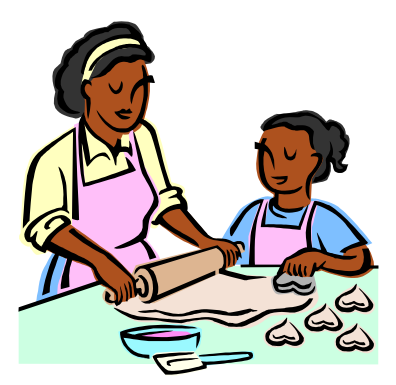

Conclusion

Your time is the most important gift you can give your child. When you spend time with your child, talking, playing, or doing whatever you both enjoy, you help your child feel loved and accepted for who he is. You are also building a good relationship that will carry into adolescence and adulthood.

\section{References}

Abasiekong, N., and Long, C. 1998. Strengthening Families Through Family Fun. Retrieved July 10, 2002 from the North Carolina State University Cooperative Extension Web site: http://www.ces.ncsu.edu/depts/fcs/smp9/parent education/familyfun.htm

Clark, L. 1996. Spending time with your children. Retrieved July 10, 2002 from the Ohio State University Cooperative Extension Web site: http://ohioline.osu.edu/hyg-fact/5000/5228.html

Greenspan, S. I. 1995. The challenging child. Cambridge, MA: Perseus Books.

Hamner, T., and Turner, P.2001. Parenting in Contemporary Society, $4^{\text {th }}$ ed. Boston, MA: Allyn \& Bacon.

Mader, S. 1998. Waiting? Have Some Family Fun Times. Retrieved July 10, 2002 from the Ohio State University Cooperative Extension Web site:

http://ohioline.osu.edu/hyg-fact/5000/5312.html 